\title{
Regime cycles and political change in African autocracies*
}

\author{
Andrea Carboni \\ School of Global Studies, University of Sussex, Falmer BNI 9SJ, UK \\ Email: A.Carboni@sussex.ac.uk \\ and \\ Clionadh Raleigh \\ School of Global Studies, University of Sussex, Falmer BNI 9SJ, UK \\ Email: C.Raleigh@sussex.ac.uk
}

\section{A B S T R A C T}

This article applies a regime cycle framework to understand patterns of change and continuity in African competitive autocracies. We observe that regime change in African autocracies is rarely the result of actions carried out by rebels, opposition leaders or popular masses substantially altering the structure of power. Instead, they are more frequently carried out by senior regime cadres, resulting in controlled reshuffles of power. We argue that such regime shifts are best explained through a cyclical logic of elite collective action consisting of accommodation and consolidation, and ultimately leading to fragmentation and crisis. These dynamics indicate the stage of leader-elite relationships at a given time, and suggest when regimes may likely expand, contract, purge and fracture. We argue that, by acknowledging in which stage of the cycle a regime and its senior elites are dominant, we can gauge the likelihood as well as the potential success of a regime change. Our framework is finally applied to understand recent regime shifts in competitive autocracies across Africa.

Keywords: Authoritarianism; Africa; regime change; elites

\footnotetext{
* The authors' work is supported by the European Research Council (ERC) within the Horizon 2020 Framework Programme on 'Violence, Elites, and Resilience in States Under Stress' (VERSUS), grant number 726504 . The authors would like to thank the anonymous reviewers for their valuable comments on earlier drafts of this article.
} 
African authoritarian regimes have incorporated a variety of democratic institutions to regulate political competition and succession. Yet, autocratic practices of power are widespread across the continent, and incumbents often use institutions as a vehicle for elite management and power reproduction (Levitsky \& Way 2010). Indeed, 'competitive autocracies' have become the dominant institutional form across the continent, and the result is a paradox: African states have institutionalised, yet several leaders have survived for decades by limiting any successful opposition, curtailing dissent, extending presidential term limits, foiling attempts to curtail central power through constitutions, and recycling loyal elites in different roles.

The 'modern authoritarian' literature argues that leaders stay in power because they distribute power and authority to senior elites and engage in successful strategies to repel threats (Bueno de Mesquita et al. 2003; Magaloni 2006; Svolik 2009). However, the integration of elites requires careful management and containment, as incumbents face the most substantial threats to their survival more from within their inner circle than from rebels, opposition leaders or popular masses. Elite management under autocracies is a rich area of investigation, yet conclusions often suggest that survival begets survival until it does not. What is missing is an explanation of internal regime shifts that acknowledges the cyclical and perpetual nature of elite management and change in autocracies. By exposing this cycle to scrutiny, we identify stages defined by high and low threats to leaders, reflecting an examination about insecurity and change within these regimes.

In recent years, recalcitrant leaders in autocratic regimes as diverse as Algeria, Sudan and Zimbabwe faced intense pressure to leave power, and were ultimately removed from their positions. Despite being heralded as successful 'regime changes', there was a striking continuity of people, systems, policies and political relationships, inviting speculation as to whether and how these removals resembled classic coups or whether they constituted radical overhauls. In all cases, incumbents were ousted by internal regime apparatchiks, who previously were loyal supporters of the former leaders. This underscores the need to concentrate on the interaction between leaders and senior elites to explain regime composition, cooperation and crisis, over investigations of opposition strength, elections, popular movements or even conflict.

Drawing on recent examples from across Africa, we offer an explanation of regime politics in competitive autocracies centred on shifts that occur amongst senior elites and their alignment with leaders. These shifts occur within a repeated cycle with four distinct phases including accommodation, consolidation, factionalisation and crisis. Long-term leaders survive many iterations of these cycles, but because the cycle stages and iterations often involve the same elites over time, the impact of these management tactics eventually wears thin. We find that the ouster of autocratic leaders was spurred by processes of factionalisation in a political coalition that preceded the crisis. 
The significance of this approach is to suggest that regime changes in autocracies rarely result in altering the structure of power; they rather produce reshuffles among the elites who hold more or less of it. Crises and extraconstitutional regime changes occur less frequently through traditional coups orchestrated by senior army officers establishing military juntas (Albrecht 2015), and more often by removing established autocrats through 'constitutional coups' in an effort to appease domestic and international publics alike (Manirakiza 2016). In competitive autocracies, change is mediated by the structure of the system: there is rarely the possibility of a revolution in authority, in part because the system is open enough to accommodate new elites who may have previously contested it from outside, but also closed enough so that power and authority remain a zero-sum game to be shared with the fewest agents possible.

Lessons observed in recent regime shifts in Algeria, Sudan and Zimbabwe offer a far more coherent narrative for how senior elite coalitions operate and fail in modern African states, and may serve as a roadmap for what could occur in other African autocracies. The inner circles and the factions that arise therein are threats to leaders, but these same senior elites are the likely building blocks of future governments after a leader is ousted (Geddes $e t$ al. 2018). These elites hold onto power during periods of change, rather than incorporating the public or the country's political opposition in any meaningful way. Other elites are 'reorganised' into a hierarchy that reflects an initial process of accommodation to gain legitimacy. This consolidation and centralisation of power creates a smaller cadre of senior elites. Competition subsequently emerges within the narrow elite cabal, and this can limit any possibility of future development or democratic transitions. This process also creates factionalisation across the surviving and ousted elites, who build networks to protect themselves from future purges. If consolidation is not managed carefully by leaders, and the successor fails to accommodate and creates factionalism, disorder and contestation at the senior level will continue and metastasize into further elite instability and violence throughout the state.

MANAGING COMPETITION IN AFRICAN AUTOCRACIES

Modern autocracies are regimes in which incumbents manipulate nominally democratic practices and institutions to their own advantage. Formally, regular elections, elected parliaments, opposition parties, and constitutional term limits constitute a bulwark against the unchecked power of incumbents. In practice, the opposition is prevented from winning power through regular channels; indeed, democratic institutions are designed not to regulate political competition, but rather to provide a semblance of democratic legitimacy to the regime (Magaloni 2006). Levitsky \& Way (2010) label these regimes as 'competitive authoritarian', representing a pervasive mode of conducting politics in contemporary Africa.

Despite the often-competitive nature and growing support for opposition parties and external elites, leaders in competitive autocracies are consumed 
with the management of senior elites within their regimes. The simple reality is that these inner circle and central regime figures sustain or destroy a leader's political survival more than the regime's external opponents can. Yet, their characteristics, factions, agendas, relationships and leverage are often underspecified in literature. Instead, much of the research on political change and continuity in modern African autocracies emphasises characteristics and impacts of critical junctures and institutions. An example of such work is 'coup politics', which explores the conditions and immediate logistics that lead to the forceful removal of a leader (Singh 2014). The existing literature tells us that coups are relatively rare, and especially so amongst established leaders (Svolik 2009), and that contemporary regime changes increasingly deviate from typical coup dynamics (Souaré 2014) and display irregular patterns (Geddes et al. 2018).

Further, rather than a focus on the continuity of regimes and politics composed of a narrow and competitive cadre of senior elites, recent crises and removals in African autocracies are recast as examples of revolutionary and transformative change through the power of social movements (Carothers \& Youngs 2015; Yarwood 2016). The role of civil society has been pushed as a key factor of change in recent cases across the African continent, including in both Sudan and Algeria (Kushkush 2019; Thomas 2019; Welborn 2019). The 'tyrants brought low by people' thesis is summarised by Hollyer et al. (2014: 764 ), who argue that 'the collapse of autocratic regimes is often brought about through large scale mobilization and collective action by elements of the populace'. In elevating the role of protest movements as catalysts of political change, these arguments were recycled widely in relation to the 2011 Arab uprisings, where mass protests are said to have caused the collapse of regimes across the region (Hale 2019). These cases, however, do not seem to suggest that the organised opposition and the public have had more relevance in bringing about a leader's removal and determining the political trajectory of a state than the defection of senior domestic elites did (Barany 2011; Hale 2013; Albrecht \& Ohl 2016).

Competitive autocracies actually display remarkable stability of institutions and constituent elites, even after sudden changes in leadership. In the wake of the removal of long-standing incumbents across Africa, the onset of volatile transitions, the entrenchment of new leaders and senior elites, the degradation of governance institutions, and limited openings of the political space, were read as signs of either authoritarian 'backsliding' or democratic breakthrough (Dresden \& Howard 2016). Notions of 'autocratisation' and 'authoritarian learning' were introduced to explain the resilience of these regimes against a supposedly teleological trajectory towards or away from democratic or autocratic ideal-types (Hall \& Ambrosio 2017; Lührmann \& Lindberg 2019). Renewed interest in the survival of African autocracies resulted in a multitude of studies focusing on coup-proofing (Makara 2013; Albrecht 2015), counterbalancing (De Bruin 2018), electoral manipulation (Blaydes 2010), clientelism (Van de Walle 2007; Liddell 2010) and patronage (Geddes 1999; Brownlee 
2007). Each of these were variously used to explain both political instability and the survival of autocratic regimes (Arriola 2009). These approaches to the study of competitive autocracies often abstracted change and continuity from real politics, and risked 'chasing events, rather than explaining or anticipating them' (Hale 2005: 134).

Despite an abundance of studies on competitive authoritarianism in Africa, academic scholarship has yet failed to situate these critical political junctures and processes within a more cohesive framework (Bogaards \& Elischer 2016). What is missing is a systematic account and assessment of the forms of political competition within these regimes; elite jostling, leadership, senior elite representation and agendas are fundamental to understanding the future actions and stability of subsequent governments.

THE AUTOCRATIC REGIME CYCLE

Insights from the political survival literature offer a more coherent narrative for explaining the overall political cycle in competitive autocracies. In particular, a common misperception of African polities is that a single leader - a 'big man' orchestrates a hierarchical patronage network of elites who exploit, suppress and extract from citizens, while not subject to any external constraints (Kuran 1991; Wintrobe 2000). When these leaders are replaced, so too are their networks. However, modern African autocracies have institutions that restrain the 'tyrannical' tendencies of any single ruler, and regulate competition among regime insiders more so than from external and opposition elements (Levitsky \& Way 2010). In such systems, the power structure requires constant strategic manipulation and management because the survival of the leader is dependent on the willingness of those around them-his 'rival allies' - to support continued rule. In other words, regime elites are the foundation of the incumbent's political survival (Raleigh \& Dowd 2018). In turn, leaders privilege two practices: spreading power around to keep it, and co-opting enough of the 'right' elites to sustain a mutually beneficial commitment (Bueno de Mesquita et al. 2003). This framing emphasises that power is transactional, and that the relationships between the leader and elites determines the level and distribution of power to be shared (Van De Walle 2007; Bove \& Rivera 2015).

The practices of power require great dexterity and political flexibility by leaders and senior elites: a leader's elite management strategies to arrange association, loyalty and alliances are variously discussed as 'political bargaining', 'political calculus', 'ethnic balancing' processes, and as a 'political marketplace' (Benson \& Kugler 1998; Goldsmith 2001; Lindemann 2011; Svolik 2012; De Waal 2015). Each details how leaders accommodate powerful elites and communities, who in turn leverage their local influence for rewards and recognition by regimes. Failing to consolidate, centralise and accommodate power between powerful elites will create incentives for future factionalisation as elites seek to organise for improved access to authority, and potentially offer an alternative 
and credible distribution of power to that of the current leader (Geddes $e t$ al. 2018).

Drawing on Hale's work on post-communist states (2005), we apply the notion of regime cycles to understand how political change in African competitive autocracies follows a logic based on elite collective action and fragmentation. The political cycle of authoritarian regimes consists of four stages, determined by the balance of power between the leader and a narrow band of senior elites. The form and magnitude of contestation between leaders and elites vary in each stage of the cycle, and the direction and character of the competition and cooperation define the dominant stage of the cycle (Higley \& Burton 1989) and the stability of a regime (see Table I). Political survival is at its height in successful consolidation after a period of accommodation. Yet, the risk of crisis is ever-present, and determined by the fault lines of factionalisation. As a result, leaders engage in different strategies to build elite coalitions during accommodation and consolidation, while factionalisation and crisis are signs of dissension and breakdown led by senior elites. It should be noted that these dynamics do not necessarily follow a chronological order, and indeed they can occur simultaneously where none is dominant.

\section{Accommodation}

In the accommodation stage, regime positions are open, and elites begin competing for offices. Accommodation occurs after a crisis, reshuffle or significant internal change, as leaders, or prospective leaders, build elite coalitions with the ultimate goal of securing an agreed distribution of authority that benefits enough senior and subnational elites (Haber 2006). This new coalition is intended to co-opt the most authoritative and coordinated group of highly networked individuals in positions of power at the national and subnational levels as well as new elites. By expanding the beneficiaries of the new regime, a coalition is stabilised and 'rooted'. Aspiring to increase its legitimacy and reach, the resulting coalition is often broadly inclusive and comprises a variety of elites, including recycled figures such as loyalists who turned, competitors who waited, regional strongmen who conquered, and technocrats who abstained. However, the ultimate power to appoint, the dispensation of authority and rents, and monopoly of and legitimate use of force remain centralised amongst the very senior elites.

Following the initial phases of accommodation, a leader should begin to unveil their specific political survival strategies. Common measures are to restrict the distribution of political rents to remunerate loyalists, counterbalance security institutions to secure their rule and access to armed forces, engage in mock trials, often around 'rooting out corruption' campaigns targeting loyalists of the former regime, and purge disposable elites. Those who remain may become the 'rival allies' within the coalition: these are typically elites whose independent leverage is important to the legitimacy and reach of the government, but whose authority and strength may compete with the leader. The 


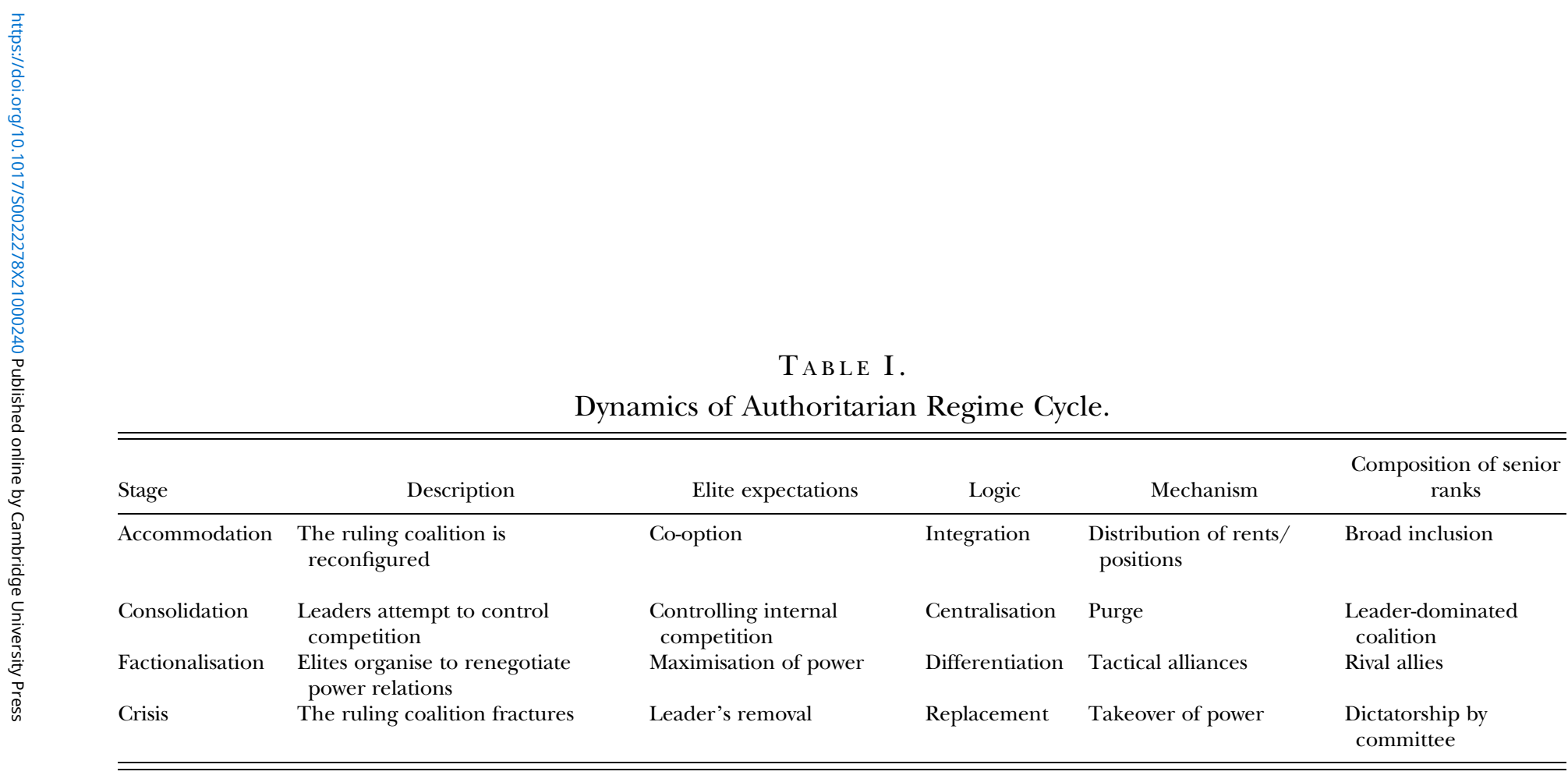


overall result is an inconsistent transition, entrenched elites, and the continued manipulation and degradation of governing and economic institutions as new leaders and senior elites extract individuals in order to build their power bases (Geddes et al. 2018). This narrowing of the accommodation phase is the lead-in to the consolidation phase.

\section{Consolidation}

Processes of consolidation are initiated when leaders seek to control competition within their own coalition (Bueno de Mesquita et al. 2003). The ultimate objective of this stage is to create an 'unbalanced equilibrium' between a dominant leader and his coalition of rival allies. The power of leaders rests in their ability to coalesce a team of elites that includes loyalists and rivals who individually cannot overthrow them, or who are unlikely to cooperate due to mutual mistrust and difficulty. In this stage, a gradual realignment of power occurs within the elites, with leaders consolidating their grip on the regime and new groups struggling to emerge as potential spoilers or challengers (Frantz \& Stein 2017). Senior elites continue to learn about each other's leverage, and actively build their own networks and patronage opportunities.

Leaders often have multiple strategies that limit the degree to which senior elites can coordinate (Powell 2012). Among these is to engage in transactional loyalty in packing cabinets, governorships, military positions and intelligence positions: while this may decrease the degree of competence in positions, as loyalty is bought but merit may not be a priority, it also acts as a survival mechanism (Sudduth 2017). Loyalists are unlikely to be key allies of conspirators and therefore can work towards mitigating coup actions in the early period. Leaders also limit alternative power centres in rival ally networks and manage risks through purging detractors, controlling political appointments, selectively sanctioning, abusing, forcing retirements, imprisoning and exiling elites associated with potentially rival factions (Cheeseman \& Klaas 2018). Likewise, leaders can increase the coordination costs among the potential factions through institutional duplication and counterbalancing (Diaz-Cayeros \& Magaloni 2001; Myerson 2008). As a result of these strategies, this is the height of a leader's independent power and the lowest risk of his being removed. This is an ongoing process and twinned with the latter repeated stages of accommodation in practice.

\section{Factionalisation}

The gravest threat facing dictators is a potential coup or usurpation by high-level individuals organised in factions (Egorov \& Sonin 2011 ; McMahon \& Slantchev 2015 ). The central driver of factionalisation is the assumption that a leader's power is overly centralised and suppressing the authority of surrounding senior elites by not 'spreading power around'. Factions host odd combinations of members, and may involve those engaged during the accommodation but 
removed during consolidation. All members work against the loyalty principle central to the architecture and composition of autocratic regimes.

By successfully building a faction, its members seek elite division. In its creation at the national level, a faction creates opposition within the regime: leaders become members of the 'dominant faction' and those not in alignment are members of an 'opposition faction', without resulting in splits from the regime or the ruling party. Because leaders are dependent on their 'elite court' to assure their continued survival, division and ruptures in the senior regime elite coalition suggest significant problems for a leader's continued power. For a faction, the work is to generate collaboration amongst some elites, and division in others. The goal is often to seek a renegotiation and new bargain for those members of the opposition faction, and they believe that organising and leveraging their collective strength vis-à-vis the dominant leader-led faction is the best option. Few factions want, or attempt, to replace the leader, and many seem to form in order to lobby for greater power access. This collective elite organisation references the leverage that is a central determinant in how regimes engage in the accommodation process. The central assumption is that a faction can 'achieve reforms through changing the balance of power in the party ... with strategies based on open collective mobilization' (Ayan Musil \& Dikici Bilgin 2016). Factions take advantage of opportunities to advance the hierarchy, thereby fracturing the coalition. Some common opportunities include economic downturns endangering distributive rents, preparation for an election, a leader's illness requiring an impromptu succession, geopolitical tensions, and increasing domestic unrest following an escalation in violence or the emergence of mass protest movements (Tilly \& Tarrow 2007). However, because these opportune moments create a favourable moment for re-negotiation and accommodation amongst many elites, they may be mistaken as the reason for crisis.

\section{Crisis}

Regime crises can occur at any point when factional bands of rival allies seek to recalibrate, seize power or oust the leader. Crises - in the form of a war, a coup or similar-do not necessarily determine the collapse of the existing political order. The form a crisis takes is dictated by the fragmentation that preceded the breakdown of a coalition, while the elites who survive in the crisis stage will be selectively accommodated in the new coalition. Regime crises produce a controlled reconfiguration of existing power structures that injects new legitimacy into the system through the disposal of the old leader, the co-option of elites and a limited opening of the political space (Gerschewski 2013). These processes are a prelude to the future centralisation of political power in the hands of a narrow ruling coalition.

An extreme and rare version of crisis is leader removal. Once initiated, removals can follow patterns that are described in the classic texts from Luttwak (1969), and in more updated interpretations from Geddes et al. 
(2018), but may also result in forced resignations, constitutional coups, or in power-sharing agreements depriving the deposed leaders of any executive power. However, a commonality across modern removals is that a 'seizing group' locates and controls the central nodes of power, disenfranchises or dissembles those who could possibly organise against the group, and quickly works to reassure other elites and assuage the mobilised public in the event of mass uprisings. While the duration of this interim phase can vary, the elite bloc who conspired to remove a leader share power in an interim 'dictatorship by committee'. Once the leader is deposed, uncertainty surrounds the regime's political trajectory as well as the intentions of the new incumbents, although this small group consisting of key regime figures typically seeks to ally with military and security elites in order to make decisions about subsequent governance structures.

We apply the observations of a cyclical process to three African competitive autocracies where long-serving incumbents were recently removed from office. The three selected case studies-Algeria, Sudan and Zimbabwerepresent autocracies where a crisis ended with a leader being ousted by former allies and senior elite factions. These regimes are at alternative stages of the cycle outlined above, but display multiple reference points to the practices relating to factionalisation, crisis, accommodation and consolidation. They also resulted in an intra-elite restructuring during accommodation, a path to consolidation and new factions that will be vulnerabilities for the leader in the upcoming crises.

THE ARMY'S POWER GRAB IN ALGERIA

In February 2019, the official announcement that the incapacitated president Abdelaziz Bouteflika would seek re-election for a fifth presidential term sparked a wave of unprecedented protests in contemporary Algeria. As the demonstrations gained momentum, drawing thousands of Algerians across the country to demand Bouteflika step down, the regime's stakeholders - a collection of ageing civilian and military elites that have ruled the country since the end of the civil war-faced increasing pressure to abandon Bouteflika. As minor concessions failed to quell the mounting discontent, ${ }^{1}$ the army's secretive Chief of Staff, Ahmed Gaïd Salah, publicly manifested his support for the protests, just a few weeks before calling for Bouteflika's formal impeachment. Faced with increasing pressure from the elites and the public, Bouteflika was forced to resign on 9 April, succeeded by the president of the Algerian Parliament's upper house, Abdelkader Bensalah.

The Algerian protests undoubtedly contributed to break a political deadlock and force the country's entrenched political elite into concessions. Described as a bulwark of stability and an emblem of exceptionalism and apathy in a region that has experienced sustained turmoil since 2011, Algeria has rarely seen meaningful political transformations over the past 20 years (Bouandel 2016). Increasing mobilisation across the Algerian public over the past years and the 
fading memory of the civil war, which had long prevented direct challenges to the regime, were signs that the country was ripe for change (Wolf 2019). The protests precipitated the crisis of the regime, which already faced a deteriorating economic situation and a yearslong political stasis.

As the crisis kicked in, Algeria's military positioned itself as the institution most capable of orchestrating and stalling change. Indeed, the army has stamped every regime since independence, and until today continues to be the main power broker despite playing a less visible role in the last two decades. Upon achieving independence in 1962, the Algerian armed forces turned from National Liberation Army into its current denomination of National Popular Army. The country's leading military institution, invested with revolutionary legitimacy, cultivated a symbiotic relationship with the Algerian state, receiving extensive constitutional prerogatives (Calchi Novati \& Roggero 2018: 197). Despite a constitutional amendment in 1989 that limited its participation in the political process, the Army's societal and economic role had ballooned, growing increasingly bigger during the civil war years (Joffé 2002).

Accommodation followed the initial crisis stage. Following the outbreak of the demonstrations, the army continued to publicly side with the protest movement by posturing as a people's army and guardian of the nation while attempting to assuage and manipulate popular demands for political change. Initial resistance to the uprisings, largely motivated by General Gaïd Salah's support for Bouteflika's candidacy, rapidly faded as opposition to the outgoing president risked dragging the army into the political dispute. Later, when plans for a managed transition faced the protesters' hostility due to the proximity of the proposed candidates to the regime, the army's Chief of Staff increasingly stepped up his public appearances, voicing support for the demonstrations and ultimately calling for Bouteflika to resign (Cristiani 2019). What motivated the army's decisions between March and April is difficult to say with certainty, as its decision-making structures are notoriously shrouded in secrecy. However, this behaviour seemed to be a reaction to an emerging scenario in which the army faced the risk of either losing its role of custodian of national stability, thus plunging the country into heightened conflict, or of being outmanoeuvred by its 'rival allies', chiefly Bouteflika and his most proximate clan consisting of family kin and business elites.

These dynamics highlight how the pact that had propped up Algeria's regime since 1999 became increasingly unsustainable, igniting a tug-of-war between its constituent elite networks. Typically described as cliques in constant competition between each other over patronage and power, these networks included the military, the security services, and Bouteflika's civilian component, along with a variety of party, civil society and bureaucratic elites that have contributed to sustain and legitimise the regime across the wider society (Roberts 2003; Werenfels 2004). In recent years, Bouteflika - and as his health deteriorated, his increasingly influential clan - attempted to centralise power to the detriment of the military and security elites striking tactical alliances for contingent 
political gains. These switching alliances, which previously brought the presidency to tactically side with either the security services or the military depending on the circumstances, succeeded in removing hostile elites such as the former army leader Mohamed Lamari in 2004 and intelligence chief Mohamed Mediène 'Toufik', forced into early retirement in 2015, and in dissolving the country's powerful intelligence agency, the Département du renseignement et de la sécurité, DRS (Fabiani 2015; Arezki 2016). In the months preceding Bouteflika's ouster, several military officials were arrested on charges of corruption and abuse of power, allegedly in an effort to purge the senior levels of the army more hostile to Bouteflika's fifth mandate (Ghemrassah 2018).

While the president's past manoeuvres managed to partially shift power from the military and security apparatus and to bring them under closer civilian supervision, these same tactics failed in March 2019. As calls for Bouteflika to step down increased, the president's clan attempted to defuse the crisis seeking support from the security services for a technocratic government that would sideline the army (Poletti 2019). The subsequent resignation of Bouteflika and the concomitant downfall of his clan-including Bouteflika's brother Saïd and some of his prominent political and business associates - highlight how this faction was critically dependent on the army's ultimate support, and the latter's pivotal, continued role in Algeria's power politics.

With Bouteflika eventually ousted, the conspirators' goal consisted of identifying and co-opting new allies from across the political landscape, entering the consolidation stage. Despite his decisive contribution to the removal of the ailing president, the army did not opt for a clear-cut, 'risky power grab' (Africa Intelligence 28.3.2019). The army instead orchestrated the selection of the post-coup regime elites supporting an extensive anti-corruption campaign to liquidate political and business elites closely associated with the former president and his clan, while recycling technocrats and politicians who had mildly opposed Bouteflika into a new, army-dominated political settlement (Ghanem 2019). To do this, the army used formal institutions, namely the judiciary and the executive, which fell under its virtual control. Dozens of Algeria's most prominent politicians and businessmen - including the former prime ministers Abdelmalek Sellal, Youcef Yousfi and Ahmed Ouyahia, Saïd Bouteflika and former intelligence chiefs Toufik and Athmane Tartag-were arrested in the weeks following Bouteflika's departure, facing years-long corruption charges (Akef 2019). Their arrests helped shore up the army's popularity among the public but were also instrumental in purging potentially dangerous opponents.

At the same time, the army orchestrated the centralisation stage through the co-option of elites believed not to constitute a threat to its hegemonic position. State bureaucrats such as Abdelkader Bensalah-former President of the Constitutional Court-and Nourredine Bedoui-former governor and Interior Minister - were appointed as interim President and Prime Minister, while a new interim cabinet largely consisting of non-party ministers was sworn in a few days after Bouteflika's resignation. Jockeying around the presidential elections, initially scheduled for April 2019, followed shortly, with a 
new vote first announced for July and then called off for the lack of credible candidates. After further pressure from the army, presidential elections were eventually called for 12 December 2019. The screening process retained five presidential candidates, four of which had served in Bouteflika's cabinets, although none of them was part of his inner circle. ${ }^{2}$ These elite reshuffles reveal that the army did not dismantle the political settlement that has ruled Algeria since the end of the civil war. It rather sought to reassemble the regime through the removal of the most proximate threats for its stabilitysuch as the Bouteflika clique, unpopular among the public and perceived as an increasingly volatile rival in the ruling coalition - and the shaping of a political class largely consisting of individuals and groups who lack a strong support base and the resources to challenge the army's dominant position through divide-and-rule strategies (Cristiani 2019). As such, the election of the independent candidate Abdelmajid Tebboune as the country's new president is unlikely to shift the power balance within the regime.

The army is likely to retain its role as a leading force in Algeria's regime, in which power is nominally exercised by a civilian government under a tutorship of the military and the security services. In Algeria's current political landscape, the country's ruling elites-and among them, the army's top brass-have manipulated opposition to Bouteflika to sustain the nascent political settlement. In this context, dissent is tolerated as long as it does not challenge the pillars of the regime or call for a radical overhaul of the system. The escalation of the army's repressive tactics and of the arrest campaign, which has increasingly targeted leaders of opposition and protest movements, suggests that dissenting voices who have not accepted to be co-opted are not contemplated in the new political order.

\section{MANAGING THE TRANSITION I N S D A N}

The events surrounding the overthrow of President Omar Al Bashir on 11 April 2019, and the subsequent negotiations for power, are often reported through the lens of the popular, public protest movement known as Forces of Freedom and Change (FFC), which swept across Sudan since December 2018. The movement arose in response to the dire economic and human rights conditions that characterised Bashir's rule. The level of protest was unprecedented in Sudan, with hundreds of cities experiencing sustained mobilisation against the regime (Matfess 2019). In the aftermath of the transition, the movement's strength resulted in Abdallah Hamdok negotiating the key position of Prime Minister. But this success should not obscure that the power in Sudan, and the dynamics of the removal, were closely related to the internal machinations of the Bashir regime. In turn, Bashir's removal was determined by select members of his inner circle and did not constitute a revolution, but an internal crisis. Although the degree to which revisions of the political system are underway is still an open question, some significant changes have occurred in Sudan, through new elites entering power and marginalising key military and paramilitary units. 
At the end of 2019, a power-sharing agreement stipulated that Sudan was to move towards a 'managed democracy' led by a civilian government, with the military exercising veto power over economic, security and political policies. For 21 months, the transition agreement period was to be chaired by the military council, and civilian-led for the subsequent 18. A Sovereign Council (SC) oversaw both legislative and minister councils, with five military and civilian members; the 11 th member to be a jointly agreed civilian. The military members all sat previously in the Transitional Military Council (TMC) formed during Bashir's removal, and were also members of Bashir's security committee (International Crisis Group 2019). All sitting members in any council of the transitional government have procedural immunity for past events. As a consequence of these combined agreements, Prime Minister Hamdok wields little to no power over politics and force in Sudan, which remain firmly in the hands of the former regime's inner circle (Watson 2020).

Two members of the SC key to understanding the current regime and its 'dictatorship by committee' are the SC head Abdel Fattah al-Burhan, and his deputy, Mohamad Hamdan Dagalo 'Hemedti'. Strongly allied from their discrediting pasts, they reorganised the Sudanese regime to their benefit. While Burhan presided over the National Intelligence Security Service (NISS), Hemedti led the Rapid Support Forces (RSF). Once a pro-government militia that worked with the NISS in Darfur, the RSF transformed from a semi-autonomous entity to be attached to the regular army in 2017. Its budget and scope were greatly increased, and its actions were placed under the direct control of President Bashir who branded Dagalo his 'protector', or 'Hemedti' (De Waal 2019). The RSF is Sudan's best equipped and largest military force, which assumed control of Khartoum at the time of Bashir's ouster. Both the intelligence services and RSF were crucial elements in Bashir's circle, and played the most significant roles in his subsequent fall.

Promoted by Burhan, Hemedti and other members of the SC, a dramatic series of events led to Bashir's removal. A quiet faction was built on frustration within Bashir's inner circle as the president proved unable to control his regime's mounting external and internal crises. The competition amongst the senior echelon of military leaders, and strong influence of Islamists around Bashir, contributed to a typical autocratic environment of distrust and elite volatility. The factionalisation put Bashir at high risk of replacement, to which he responded by removing different senior leaders. For example, a previous NISS leader, Salah Gosh, was ousted in 2009 and imprisoned in 2011 before being released and reinstated in a senior position in 2018 (Berridge 2020). Bashir's former Chief of Staff and close advisor, Taha Osman al-Hussein, was accused of working on behalf of Saudi Arabia, and removed from his post, only to return during the coup as a Saudi representative. Bashir's excessive counter-balancing had weakened the security services, and paramilitary organisations were increasingly prominent towards the end of the Bashir's tenure through transactional loyalties.

Of those elites who populated Bashir's later regime posts, few remain. Burhan and Hemedti soon constituted a 'dictatorship by committee', and were 
reluctant to distribute authority, appointments or rents much further than those who joined the TMC (Jo 2019). The SC's military members are closely associated with the exceedingly small group that removed Bashir, consisting of Burhan, Hemedti, and other senior security officials (Africa Confidential $2019^{a}$ ). Between them, they have a monopoly of force, the power to appoint, the control of rents and total discretion over economic, security and political policies. However, they have also made concessions to create a public face of the regime, including the co-option of members of political parties and civil society with little authority or decision-making power.

For these reasons, the accommodation dynamics of the current Sudanese government are conducted as two separate engagements: a public front populated by various members of civil society and resuscitated parties who vie for renewed recognition, and those who engage with the key members of the Sovereign Council. But while Burhan and Hemedti are concerned with the accommodation of regional elites and forces and high value senior elites, hundreds of arrests have taken place during a purge of the security services (Africa Intelligence 10.5 .2019 ).

As the early post-Bashir regime consolidated, several TMC members reiterated the importance of Hemedti, who emerged as the most important political figure in Sudan as deputy leader of the TMC that ruled Sudan between April and August 2018 (Africa Intelligence 1.11.2019). His role as the power-broker between post-Bashir political elites was built on both his monopoly of violence and his claim to peripheral bridge-building. His control of the RSF, extensive economic rents through mining revenues and payments, and his political backing from the Saudi and UAE governments give him significant authority (De Waal 2019). His power of appointments is not consolidated, but he exerts significant veto power and purging abilities. Hemedti's fortune is also extensive, built from appropriation of gold resources and participation to the war in Yemen where the RSF has operated as Saudi Arabia's mercenary force (Tubiana 2019). Additionally, he cleverly positioned his 'populist' alliance by bolstering the representation of Darfuri rebel and militia leaders, engaging with Kordofani chiefs, and seeking support from tribal authorities previously rebuked by senior military elites. He courted peripheral or removed players in Sudanese politics by engaging with former military officers, armed movements, and the now disbanded National Congress Party. This coalition is unknown in Sudan as Bashir focused largely on security professionals (De Waal 2019).

Hemedti also knit together fragments of the larger political environment that were previously distorted and suppressed, and all suffered from an economic crisis that prevented serious attempts at political transactions and consolidations. Before being removed, Bashir fired all governors, ministers and mayors, replacing them with rank loyalists. In contrast, Hemedti and Burhan generated a multi-ethnic, cross regional, group with no individually powerful members. They were a duopoly running the Sudanese government from behind a very thin veil. Both are unlikely to be removed through any public or elite processes: 
they increased their co-dependence, while generating a wide, inclusive and violent coalition to support their continued power (Watson 2020). When the accommodation period elapses, it increasingly appears that this unique powerbase will be deployed against the supporters of a civilian government in a consolidation phase.

\section{Z I M B A B WE'S SECON D REPUBLIC}

In November 2017, President Robert Mugabe of Zimbabwe was ushered out of power in a series of military and party-assisted manoeuvres that culminated in the presidency of Emerson Mnangagwa and the elevation to Vice President for General Constantino Chiwenga (Fabricus 2018). Mnangagwa came to power through senior positions in both the ZANU-PF party and Mugabe's regime. From his last post of Vice President, he created the 'Lacoste' faction, which openly recruited amongst the most senior political elites in Mugabe's government, involved the co-option of multiple provincial coordinating committees, and integrated the War Veterans and military elites (Raleigh 2017). The faction openly contradicted Mugabe's personalisation of power through the centralisation of authority in his family and inner circle (Allison 2017), and suffered from the long decline of Mugabe's regime characterised by purges, high level firings, suspicious deaths, questionable election totals, a bankrupted economy, land seizures for political elites, firing and replacements of local and provincial level officials and episodes of targeted violence (Dzirutwe 2014; Raleigh 2018).

To limit the power of internal challengers, Mugabe rewarded loyalty, replaced ambitious contenders and threatened the position of others. The 'pro-Mugabe' faction were commonly referred to as 'Generation 40', or G-40, and characterised by their relative youth compared with senior party members, the general lack of ties to the liberation struggle, their hostility towards the War Veterans group, the senior military command, and their attempted co-option of the security services. Mugabe placed several figures affiliated with the G-40, including former ministers Saviour Kasukuwere and Jonathan Moyo, in key positions to create obstacles for Lacoste and advance threatening Mnangagwa's position in power. Crisis erupted when Mugabe, facing illness and advanced age, did not have the means to placate, pay for and otherwise secure the loyalty of his supposed loyalists. Following patterns outlined in Bueno De Mesquita et al. (2003), these circumstances encouraged Lacoste's ambitious elites to replace their ineffective leader. The removal and crisis, when it reached a tipping point in November 2017, was largely farcical: Mugabe attempted to accommodate the interests of the Lacoste faction, and resisted leaving until the parliament was posed to vote for his replacement (Graham-Harrison \& Burke 2017).

The group that initiated the crisis was led by Mnangagwa and the former head of the security services, Constantine Chiwenga, who recruited potential allies amongst the top echelons of the armed forces. Mnangagwa and Chiwenga entered into a phase of accommodation soon after assuming their positions 
of President and Vice President. The Lacoste faction were well placed in senior positions, as were elites with significant leverage in other political networks, regions or potential voting areas. Many of the co-opted elites had served in Mugabe's previous cabinets. While these elites were not originally in the Lacoste faction, their positions exploited their individual clout for the stability of the new government, and their inclusion sent a message that not all pro-Mugabe ZANU-PF party elites would be purged. ${ }^{3}$ Only those who had strong ties to the now defunct G-40 faction were initially expelled in November 2017 , while no representatives from the opposition or civil society were actively included. Further, Vice President Chiwenga widely appointed military figures to civilian cabinet posts, including Air Force leader Perrance Shiri's appointment as Agriculture Minister, and Sibusiso Moyo as Foreign Affairs Minister. Chiwenga also served as Defence Minister in the first year of government.

The accommodation in the early part of the transition government suggested a 'stability-elite' pact: it allowed both Mnangagwa and Chiwenga to pursue respective goals by distributing power, rather than centralising it. These actions were designed to settle the political class, and to pursue the early election agenda. The 'dictatorship by committee' kept power by sharing it with others, and successfully navigated through the 2018 elections.

The election secured Mnangagwa's position into the near future and ended accommodation. The election resulted in the loss of $5^{2}$ 'safe' ZANU-PF seats, which indicated that Mnangagwa would need to fortify and consolidate his regime into a smaller, more loyal group to continue his agenda. As a result, the president made several sweeping changes to the composition of his ruling coalition, purging elites who no longer served an electoral purpose, and were not a threat to government. 4 During this consolidation phase, the most significant change was the removal of Chiwenga from the Ministry of Defence, reflecting Mnangagwa's increasing autonomy from the Vice President and his network (Chan 2019). While Mnangagwa enjoyed the support of senior ZANU-PF heavyweights and influential business and international communities, Chiwenga's faction consisted of former military personal and middle level security service figures who were highly dependent on the kickbacks and patronage of the service.

The result of the consolidation process is that Mnangagwa's power was largely unchecked by political elites: the former faction of Lacoste had been integrated, the opposition unmoored and unable to gain traction in any formal positions, and Vice President Chiwenga lost the power to challenge or contest the president. Mnangagwa loyalists dominated cabinet (Africa Confidential 2019b) . These moves confirmed that the President used his superior authority to lessen or remove the influence of close elite, thereby securing his own consolidated authority. The next step in this process was the factionalisation of the regime, hastened by the desperate economic situation of the state. A recent report confirms that the competition between Mnangagwa and Chiwenga has created deep factional divides within the state (Africa Confidential 2020). 
In this article, we proposed a framework to understand regime shifts and reconstitution in African autocracies through a logic of elite collective action. In these regimes, the ouster of incumbents is rarely the result of a sudden rise in instability, nor they are overthrown by organised oppositions, violent non-state groups or public protest alone. Instead, we argued that African competitive autocracies are not transitioning towards democracy, nor entrenching into full-fledged autocracies, but are rather following largely predictable patterns of regime cycles consisting of several interlocking stages of elite accommodation, consolidation, factionalisation and crisis. These stages do not constitute a chronological sequence - indeed they may occur simultaneously - but rather describe how a regime cycle is produced through authoritarian practices and operates according to political survival logics. External challenges may expose a regime's vulnerability, but have little impact on the reconfiguration of power that follows the ouster of incumbents.

We applied our framework to understand the dynamics that preceded and followed recent regime crises in three African autocracies. We argued that, although their leaders had a combined go years in power, the ouster of Algeria's Bouteflika, Sudan's Bashir and Zimbabwe's Mugabe is best viewed as moments in a regime cycle where senior elite actors have taken advantage of ripened factionalism to seize power and reconfigure inter-elite relations. These ageing autocrats were removed by regime insiders, who went on to reconstitute regimes that follow similar practices and policies. In no cases have regimes been cleansed of their previous powerholders, with the exception of the ousted leaders and their closest loyalists. Powers of appointment and veto, control of violent means, and means of rent allocation still reside in the hands of senior elites who previously collaborated with the outgoing leaders.

In the cases covered here, all leaders engaged in significant reshuffles, replacements, firings and counterbalancing to sustain their tenure. But these practices, although central to political survival, traded one risk for another, rather than mitigating threats. In Algeria, during the months prior to the uprisings, Bouteflika's clan purged hostile elements from the intelligence services and the army. Rather than seizing power directly, the army assembled a coalition of bureaucrats and political figures loosely associated with the regime through which it could assuage the masses and keep control of the country's national institutions. In Sudan, Bashir fired his cabinet and all regional governors in the months preceding his ouster, but did little to alter the structure of the armed forces, in part because he had extensively counter-balanced those forces before, and continued to rely on them. A combination of his most senior elites in intelligence and paramilitary forces quickly removed him. In Zimbabwe, Mugabe shuffled elites, purged the ambitious, arrested opposing factions, supported the rise of other factions, sidelined long-term allies, and so forth. Mugabe kept enemies close both to observe their behaviour, but also because 
he was vulnerable without them: they were the senior members of his government. A ready-made shadow state replaced him.

In each of the cases noted, the senior elites who replaced the leaders pursued extensive accommodation to increase the legitimacy and elite 'buy-in' for the new regime. At this stage of the cycle, the new regime is vulnerable to counter-removals, and co-opts widely to integrate and leverage the multiple power centres across the state. When secure in their positions, new leaders will consolidate their power by removing any elements of their regime who may counter their authority going forward. This stage represents the height of a leader's powers, and the most unstable period for regime elites, as leaders purge and move elites to suit their centralisation agenda. Excessive personalisation and consolidation, in turn, produces the impetus for elite collective action to check the power of the executive through factions, thereby restarting a process of instability and possible leader removal.

In identifying predictable cycles of elite collective action, we suggest that this approach may come to constitute a useful conceptual framework to interpret dynamics in other African autocracies. While the occurrence of public protests, elections and coups that drive regimes towards autocracy or democracy cannot be dismissed, the logic proposed in this article highlights how significant political changes are the product of continuous, cyclical interactions between incumbents and senior elites. Within this cycle, stalemate, rather than outright predominance, is more likely to produce a democratic breakthrough (Rustow 1970). Across the continent, several authoritarian regimes - such as Burundi, Chad, Equatorial Guinea, the Republic of Congo, Rwanda, South Sudan, Tanzania and Uganda-currently oscillate between the consolidation and factionalisation phases. Rather than expecting these regimes to transition into democracies when their established leaders fall, they are likely to be reconstituted as slightly more unstable versions of their current states.

The application of this framework may produce new research insights. First, further work should be devoted to the factors that amplify oscillations within regime cycles. Leaders' personalities, domestic and international institutional constraints, ideologies and discourses, as well as local political economies may accelerate or slow down transitions towards factionalisation, crisis, accommodation and consolidation. Despite their striking similarities, the three selected case studies presented in this article resulted in distinct institutional outcomes and patterns of violence, influenced by perceptions of insecurity and varying degrees of international involvement. A second direction of research will be to investigate empirically the differences among the stages in the regime cycle. The availability of new data shedding light on the composition of regimes in Africa and elsewhere (De Bruin 2020; Raleigh \& Wigmore Shepherd 2020) allows a more granular and systematic analysis of institutional inclusion and representation in authoritarian regimes. By situating them within different stages of the regime cycle, our approach could further account for variations in the use of institutional buy-in within and across states. 


\section{NOTE S}

1. Two weeks after the protests began, Bouteflika fired his unpopular campaign director Abdelmalek Sellal, replacing him with the Transport Minister Abdelghani Zaalane. Bouteflika then announced he would not seek a new term.

2. Former Prime Minister and head of the ruling Front de Libération Nationale (FLN) Ali Benflis ran against Bouteflika in the 2004 and 2014 presidential elections. Abdelmajid Tebboune briefly served as prime minister in 2017. Azzedine Mihoubi and Abdelkader Bengrina also served in ministerial capacity during Bouteflika's presidency.

3. These figures included Presidential Affairs Minister Simbarashe Mumbengegwi and Home Affairs Minister Obert Mpofu.

4. Those purged included Simon Kaya Moyo (Matabeleland South), Patrick Chinamasa (Manicaland), Pupurayi Togarepi (Masvingo), Simbarashe Mumbengegwi (Midlands), and others.

\section{REFERENCES}

Africa Confidential. 2019a. 'The revolution rumbles on', Africa Confidential 6o, 8: 1-4.

Africa Confidential. 2019 b. 'Mourning and machinations', Africa Confidential 6o, 18: 3 .

Africa Confidential. 2020. 'Power struggles and inflation', Africa Confidential 61, 2: 10-1 1.

Albrecht, R. 2015. 'The myth of coup-proofing: risk and instances of military coups d'état in the Middle East and North Africa, 1950-2013', Armed Forces and Security 41, 4: 659-87.

Albrecht, H. \& D. Ohl. 2016. 'Exit, resistance, loyalty: military behavior during unrest in authoritarian regimes', Perspectives on Politics 14, 1: $3^{8-} 5^{2}$.

Allison, S. 2017. 'Zimbabwe's succession race is far from over', Institute for Security Studies, 8 November. $<$ https://issafrica.org/iss-today/zimbabwes-succession-race-is-far-from-over >, accessed 6.1.2021.

Arezki, S. 2016. 'Un demi-siècle d'histoire du renseignement algérien', Afrique Contemporaine 260, 4: 78-82.

Arriola, L. 2009. 'Patronage and political stability in Africa', Comparative Political Studies 42, 10 : 1339-62.

Ayan Musil P. \& H. Dikici Bilgin. 2016. 'Types of outcomes in factional rivalries: lessons from non-democratic parties in Turkey', International Political Science Review 37, 2: 166-83.

Barany, Z. 2011. 'The role of the military', Journal of Democracy 22, 4: 28-39.

Benson, M. \& J. Kugler. 1998. 'Power parity, democracy, and the severity of internal violence', Journal of Conflict Resolution 42, 2: 196-209.

Berridge, W.J. 2020. 'Briefing: the uprising in Sudan', African Affairs 11 19, 1: 164-76.

Blaydes, L. 2010. Elections and Distributive Politics in Mubarak's Egypt. Cambridge: Cambridge University Press.

Bogaards, M. \& S. Elischer (eds) 2016. 'Competitive authoritarianism in Africa revisited', in Democratization and Competitive Authoritarianism in Africa. Wiesbaden: Springer VS, $5^{-18}$.

Bouandel, Y. 2016. 'The Arab Spring and Algeria's exceptionalism.' Paper presented at the Second International Conference on Social Sciences, Istanbul, Turkey, 2-3 April.

Bove, V. \& M. Rivera. 2015. 'Elite co-optation, repression, and coups in autocracies', International Interactions 41, 3: 453-79.

Brownlee, J. 2007. Authoritarianism in an Age of Democratization. Cambridge: Cambridge University Press.

Bueno de Mesquita, B., A., Smith, J.D. Morrow \& R.M. Siverson. 2003. The Logic of Political Survival. Cambridge, MA: MIT Press.

Calchi Novati, G. \& C. Roggero. 2018. Storia dell'Algeria Indipendente: dalla guerra di liberazione a Bouteflika. Milan: Bompiani.

Carothers, T. \& R. Youngs. 2015. 'The complexities of global protests', Carnegie Endowment for International Peace, 8 October. <https://carnegieendowment.org/2015/10/o8/complexities-of-global-protests-pub$61537>$, accessed 6.1.2021.

Chan, S. 2019. 'Zimbabwe: three reasons why it's all going so wrong for Mnangagwa', The Conversation, 13 February. <https://theconversation.com/zimbabwe-three-reasons-why-its-all-going-so-wrong-for-mnangagwa-1 $11443>$, accessed 6.1.2021.

Cheeseman, N. \& B. Klaas. 2018. How to Rig an Election. New Haven, CT: Yale University Press.

Cristiani, D. 2019. 'Forward ... but where to?', Cairo Review of Global Affairs 34, 2.

De Bruin, E. 201 8. 'Preventing coups d'état: how counterbalancing works', Journal of Conflict Resolution 62, $7: 1433-5^{8}$.

De Bruin, E. 2020. 'Mapping coercive institutions: the State Security Forces dataset, 1960-2010', Journal of Peace Research. 
De Waal, A. 2015. The Real Politics of the Horn of Africa: money, war and the business of power. Cambridge: Polity Press.

De Waal, A. 2019. 'Sudan: a political marketplace framework analysis', World Peace Foundation, Occasional Papers 19. <http://eprints.lse.ac.uk/101291/1/De_Waal_Sudan_a_political_marketplace_analysis_ published.pdf $>$, accessed 6.1.2021.

Diaz-Cayeros, A. \& B. Magaloni. 2001. 'Party dominance and the logic of electoral design in Mexico's transition to democracy', Journal of Theoretical Politics 13, 3: 271-93.

Dresden, J.R. \& M.M. Howard. 2016. 'Authoritarian backsliding and the concentration of political power', Democratization 23, 7: $1122-43$.

Egorov, G. \& K. Sonin. 2011. 'Dictators and their viziers: endogenizing the loyalty-competence trade-off', Journal of the European Economic Association 9, 5: 903-3o.

Fabricus, P. 2018. 'Will Mnangagwa pull off another 'coup' this year?', Institute for Security Studies, 18 January. $<$ https://issafrica.org/iss-today/will-mnangagwa-pull-off-another-coup-this-year>, accessed 6.1.2021.

Frantz, E. \& E.A. Stein. 2017. 'Countering coups: leadership succession rules in dictatorships', Comparative Political Studies $5^{\mathrm{o}, 7}$ : $935^{-62 .}$

Geddes, B. 1999. 'What do we know about democratization after twenty years?', Annual Review of Political Science 2, 1: $115^{-44}$.

Geddes, B., E. Frantz \& J. Wright. 2018. How Dictatorships Work: power, personalization, and collapse. Cambridge: Cambridge University Press.

Gerschewski, J. 2013. 'The three pillars of stability: legitimation, repression, and co-optation in autocratic regimes', Democratization 20, 1: 13-38.

Goldsmith, A.A. 2001. 'Donors, dictators and democrats in Africa', Journal of Modern African Studies 39, 3: $411-36$.

Haber, S. 20o6. 'Authoritarian government', in B. Weingast \& D. Wittman, eds. Oxford Handbook of Political Economy. Oxford: Oxford University Press, 693-707.

Hale, H.E. 2005. 'Regime cycles: democracy, autocracy, and revolution in Post-Soviet Eurasia', World Politics $5^{8,1: 133-65}$.

Hale, H.E. 2013. 'Regime change cascades: what we have learned from the 1848 revolutions to the 2011 Arab uprisings', Annual Review of Political Science 16, 1: $33^{1-53}$.

Hale, H.E. 2019. 'How should we now conceptualize protest, diffusion, and regime change?', Journal of Conflict Resolution 63, 10: 2402-15.

Hall, S.G.F. \& T. Ambrosio. 201 7. 'Authoritarian learning: a conceptual overview', East European Politics 33, 2: $143^{-61 .}$

Higley, J. \& M. Burton. 1989. 'The elite variable in democratic transitions and breakdowns', American Sociological Review 54, 1: 17-32.

Hollyer, J., B. Rosendorff \& J. Vreeland. 2014. 'Measuring transparency', Political Analysis 22, 4: 413-34. International Crisis Group. 2019. 'Safeguarding Sudan's revolution', Crisis Group Africa Report no. 281, 21 October. <https://www.crisisgroup.org/africa/horn-africa/sudan/28 1-safeguarding-sudans-revolution>, accessed 6.1.2021.

Joffé, G. 2002. 'The role of violence within the Algerian economy', Journal of North African Studies 7, 1: 29-52.

Kuran, T. 1991. 'Now out of never: the element of surprise in the East European revolution of 1989', World Politics 44, 1: $7-48$.

Levitsky, S.R. \& L.A. Way. 2010. Competitive Authoritarianism: hybrid regimes after the Cold War. Cambridge: Cambridge University Press.

Liddell, J. 2010. 'Notables, clientelism and the politics of change in Morocco', Journal of North African Studies $15,3: 315^{-31}$.

Lindemann, S. 2011. 'The ethnic politics of coup avoidance: evidence from Zambia and Uganda', Africa Spectrum 46, 2: $3-41$.

Lührmann, A. \& S.I. Lindberg. 2019. 'A third wave of autocratization is here: what is new about it?', Democratization 26, 7: 1095-13.

Luttwak, E.N. 1969. Coup d'État: A Practical Handbook. London: Penguin Books.

Magaloni, B. 20o6. Voting for Autocracy: hegemonic party survival and its demise in Mexico. Cambridge: Cambridge University Press.

Makara, M. 2013. 'Coup-proofing, military defection, and the Arab Spring', Democracy and Security 9, 4: $334-59$.

Manirakiza, P. 2016. 'Insecurity implications of unconstitutional changes of government in Africa: from military to constitutional coups', Journal of Military and Strategic Studies 1 7, 2: 86-1o6. 
Matfess, H. 2019. 'Pressure points: Sudan's state of emergency and anti-government demonstrations', ACLED, 28 February. <https://acleddata.com/2019/o2/28/pressure-points-sudans-state-of-emergency-and-anti-government-demonstrations/>, accessed 6.1.2021.

McMahon, R.B. \& B.L. Slantchev. 2015. 'The guardianship dilemma: regime security through and from the armed forces', American Political Science Review 109, 2: 297-313.

Myerson, R.B. 2008. 'The autocrat's credibility problem and foundations of the constitutional state', American Political Science Review 102, 1: $125^{-39}$.

Powell, J.M. 2012. 'Determinants of the attempting and outcome of coups d'état', Journal of Conflict Resolution 56, 6: 1017-40.

Raleigh, C. 2018. 'Radar-Zimbabwe pre-election report 2018', ACLED, 3o July. <https://acleddata.com/ 2018/07/30/radar-zimbabwe-pre-election-report-2018/>, accessed 6.1.2021.

Raleigh, C. \& C. Dowd. 2018. 'Political environments, elite co-option, and conflict', Annals of the American Association of Geographers 108, 6: 1668-84.

Raleigh, C. \& D. Wigmore-Shepherd. 2020. 'Elite coalitions and power balance across African regimes: introducing the African Cabinet and Political Elite Data Project (ACPED)', Ethnopolitics.

Roberts, H. 2003. The Battlefield: Algeria 1988-2002. Studies in a broken polity. London: Verso.

Rustow, D. 1970. 'Transitions to democracy: towards a dynamic model', Comparative Politics 2, 3: 337-63.

Singh, N. 2014. Seizing Power: the strategic logic of military coups. Baltimore, MD: Johns Hopkins University Press.

Souaré, I. 2014. 'The African Union as a norm entrepreneur on military coups d'état in Africa (1952201 2): an empirical assessment', Journal of Modern African Studies 52, 1: 69-94.

Sudduth, J.K. 2017. 'Coup risk, coup-proofing and leader survival', Journal of Peace Research 54, 1: $3^{-1} 5$.

Svolik, M.W. 2009. 'Power sharing and leadership dynamics in authoritarian regimes', American Journal of Political Science 53, 2: 477-94.

Svolik, M.W. 201 2. The Politics of Authoritarian Rule. Cambridge: Cambridge University Press.

Tilly, C. \& S.G. Tarrow. 2007. Contentious Politics. Boulder, CO: Paradigm Publishers.

Tubiana, J. 2019. 'The man who terrorized Darfur is leading Sudan's supposed transition', Foreign Policy, 14 May. <https://foreignpolicy.com/2019/o5/14/man-who-terrorized-darfur-is-leading-sudans-supposedtransition-hemeti-rsf-janjaweed-bashir-khartoum/>, accessed 6.1.2021.

Van de Walle, N. 2007. 'Meet the new boss, same as the old boss? The evolution of political clientelism in Africa', in H. Kitschelt \& S. Wilkinson, eds. Patrons, Clients, and Policies: patterns of democratic accountability and political competition. Cambridge: Cambridge University Press, $5^{\mathrm{O}-67}$.

Watson, D. 2020. 'Danse macabre: revolution and counter-revolution in post-oil Sudan', ACLED, 12 October. <https://acleddata.com/2020/10/12/danse-macabre-revolution-and-counter-revolution-inpost-oil-sudan/>, accessed 6.1.2021.

Welborn, L. 2019. 'Algeria, Sudan and the power of protest', Institute for Security Studies, 24 May. <https:// issafrica.org/iss-today/algeria-sudan-and-the-power-of-protest>, accessed 6.1.2021.

Werenfels, I. 2004. 'Algeria: system continuity through elite change', in V. Perthes, ed. Arab Elites: negotiating the politics of change. Boulder, CO: Lynne Rienner, 173-206.

Wintrobe, R. 200o. The Political Economy of Dictatorship. Cambridge: Cambridge University Press.

Wolf, A. 2019. 'The myth of stability in Algeria', Journal of North African Studies 24, 5: 707-12.

Yarwood, J. 2016. 'The power of protest', Journal of Democracy 27, 3: $5^{1-60 .}$

\section{Newspapers}

Africa Intelligence, Paris. 2019. 'Ahmed Gaid Salah opts for risky power grab', 28 March. <https://www. africaintelligence.com/mce/corridors-of-power/2019/o3/28/ahmed-gaid-salah-opts-for-risky-powergrab, 108351128 -eve>, accessed 6.1.2021.

Africa Intelligence, Paris. 2019. 'Hemeti, kingmaker or future king', 10 May. <https://www.africaintelligence.com/ion/corridors-of-power/2019/05/10/hemeti-kingmaker-or-future-king, 108356554 -gra>, accessed 6.1.2021.

Africa Intelligence, Paris. 2019. 'Major purge of Sudanese army', 1 November. <https://www.africaintelligence.com/ion/corridors-of-power/2019/11/o1/major-purge-of-sudanese-army,108379839-bre>, accessed 6.1.2021.

Akef, A. 2019. 'Algérie: Saïd Bouteflika, ex-«homme de l'ombre» du régime, condamné à quinze ans de prison', Le Monde, Paris, 25 September. <https://www.lemonde.fr/afrique/article/2019/og/25/ algerie-said-bouteflika-ex-homme-de-l-ombre-du-regime-condamne-a-quinze-ans-de-prison_6o $12953-3212$. html $>$, accessed 6.1.2021. 
Dzirutwe, M. 2014. 'Zimbabwe's Mugabe fires deputy, seven ministers', Reuters, London, 9 December. <https://www.reuters.com/article/us-zimbabwe-mujuru/zimbabwes-mugabe-fires-deputy-seven-ministers-idUSKBNoJNoP $420141209>$, accessed 6.1.2021.

Fabiani, R. 2015. 'The changing nature of the Algerian political system and the illusion of a civilian regime', Jadaliyya, Beirut, 6 August. <https://www.jadaliyya.com/Details/32346>, accessed 6.1.2021.

Ghanem, D. 2019. 'How Algeria's military is shaping the country's political transition', Middle East Eye, London, 16 September. <https://www.middleeasteye.net/opinion/how-military-has-shaped-algeriaspolitical-transition>, accessed 6.1.2021.

Ghemrassah, B. 2018. 'Algerian army: five generals behind bars on corruption charges', The North Africa Post, Rabat, ${ }_{5}$ October. <https://northafricapost.com/25818-algeria-five-generals-behind-bars-oncorruption-charges.html>, accessed 6.1.2021.

Graham-Harrison, E. \& J. Burke. 201 7. 'Impeachment proceedings against Mugabe begin in Zimbabwe', The Guardian, London, 21 November. <https://www.theguardian.com/world/2017/nov/21/robertmugabe-impeachment-proceedings-begin-in-zimbabwe-emmerson-mnangagwa>, accessed 6.1.2021.

Jo, A. 2019. 'La révolution soudanaise face à ses ennemis', Orient XXI, Paris, ${ }_{15}$ April. <https://orientxxi. info/magazine/la-revolution-soudanaise-face-a-ses-ennemis,3031\#nb3>, accessed 6.1.2021.

Kushkush, I. 2019. 'Protesters in Sudan and Algeria have learned from the Arab Spring', The Atlantic, Washington, D.C., 13 April. <https://www.theatlantic.com/international/archive/2019/o4/protesters-sudan-and-algeria-have-learned-arab-spring/587113/>, accessed 6.1.2021.

Poletti, A. 2019. “ «Complot» en Algérie: quels liens entre les protagonistes présumés?', Jeune Afrique, Paris, 18 May. <https://www.jeuneafrique.com/776589/politique/infographie-complot-en-algerie-quelsliens-entre-les-protagonistes-presumes $>$, accessed 6.1.2021.

Raleigh, C. 2017. 'Here's what's happening in Zimbabwe', The Washington Post, Washington, DC, 15 November. <https://www.washingtonpost.com/news/monkey-cage/wp/2017/11/15/heres-whatshappening-in-zimbabwe/>, accessed 6.1.2021.

Thomas, D. 2019. 'Demographic change brings down Africa's veterans', African Business, London, 23 April. $<$ https://africanbusinessmagazine.com/opinion/demographic-change-brings-down-africas-veterans/>, accessed 6.1.2021. 